\title{
THE EFFECT OF BLENDED LEARNING TOWARD MEMORY RETENTION RATES OF NEONATAL RESUSCITATION SKILLS AND STUDENT'S PERCEPTION
}

\author{
Veratiwi $^{1 *}$, Nanan Sekarwana², Ike Rostikawati Husen ${ }^{2}$ \\ ${ }^{1}$ Program Studi Magister Kebidanan Fakultas Kedokteran Universitas Padjajaran, Bandung - INDONESIA \\ ${ }^{2}$ Departemen IImu Kesehatan Anak Fakultas Kedokteran Universitas Padjajaran, Bandung - INDONESIA
}

\begin{abstract}
Background: Retention is a goal in the learning process. The objective of this study was to compare the memory retention rates of neonatal resuscitation skills between blended learning strategies and conventional ones and to analyze the correlation of students' perception on the implementation of blended learning towards memory retention rates of neonatal resuscitation skills.

Method: This was an analytical study using quasi-experimental design applying posttest-only non-equivalent group design. The subjects of this study were students of DIII Midwifery Program of Health Polytechnic Palembang. The research subjects were divided into two groups; 25 subjects in blended learning group and 25 subjects in conventional group. The hypotheses were tested using Kolmogorov-Smirnov, to analyze the differences of memory retention rates of resuscitation skills between the two groups of study, and Chi-square test, to see the correlation of students' perception on the implementation of blended learning with memory retention rates of resuscitation skills.

Result: The results of study showed that the memory retention rates of neonatal resuscitation skills between blended learning group and conventional group were not significantly different. In addition, there was no correlation of students' perception on the implementation of blended learning toward the memory retention rates of resuscitation skill.

Conclusion: From the findings of this study, it can be concluded that there was no difference in the memory retention rates of neonatal resuscitation skills between blended learning strategies and conventional ones and there was no effect of the students' perception on the implementation of blended learning towards the memory retention rates of neonatal resuscitation skills.
\end{abstract}

Keywords: blended learning, memory retention rates, neonatal resuscitation skills, perception

\begin{abstract}
ABSTRAK
Latar Belakang: Retensi merupakan tujuan dalam proses pembelajaran. Tujuan penelitian ini adalah untuk membandingkan tingkat retensi memori keterampilan resusitasi neonatus antara strategi blended learning dengan konvensional dan menganalisis pengaruh persepsi mahasiswa tentang implementasi blended learning terhadap tingkat retensi memori keterampilan resusitasi neonatus.

Metode: Penelitian ini merupakan penelitian analitik menggunakan desain quasi experiment dengan rancangan posttest only non equivalent group design. Subyek penelitian adalah mahasiswa Program Studi D III Kebidanan Poltekkes Palembang yang terbagi menjadi 25 orang kelompok blended learning dan 25 orang kelompok konvensional. Uji hipotesis menggunakan uji Kolmogorov-Smirnov untuk melihat perbedaan tingkat retensi keterampilan resusitasi antara kedua kelompok, dan uji Chi-square untuk melihat hubungan persepsi mahasiswa tentang implementasi blended learning terhadap tingkat retensi memori keterampilan resusitasi.
\end{abstract}

*corresponding author, contact: sweety_daver@yahoo.com 
Hasil: Tingkat retensi memori keterampilan resusitasi neonatus antara kelompok blended learning dan kelompok konvensional tidak berbeda secara bermakna, dan tidak terdapat hubungan antara persepsi mahasiswa tentang implementasi blended learning terhadap tingkat retensi memori keterampilan resusitasi.

Kesimpulan: Tidak terdapat perbedaan tingkat retensi memori keterampilan resusitasi neonatus antara strategi blended learnig dengan konvensional dan tidak ada pengaruh persepsi mahasiswa tentang implementasi blended learning terhadap tingkat retensi memori keterampilan resusitasi neonatus.

Kata kunci: blended learning, tingkat retensi memori, keterampilan resusitasi neonataus, persepsi

\section{PENDAHULUAN}

Dalam upaya meningkatkan kualitas pendidikan bidan berkualitas dan kompeten sebagaimana tercantum dalam tujuan keempat Sustainable Development Goals (SDGs) atau yang dikenal sebagai "Pendidikan 2030", yang bunyinya "memastikan pendidikan berkualitas yang layak dan inklusif serta mendorong kesempatan belajar seumur hidup bagi semua orang, kesempatan belajar seumur hidup di semua pendidikan formal maupun non formal", adalah dengan menerapkan suatu model strategi pembelajaran yang tepat. ${ }^{1}$ Pendidikan bidan sebagai pendidikan vokasional, lebih menitikberatkan pada penguasaan keterampilan (60\%) dibandingkan penguasaan konsep teori $(40 \%){ }^{2}$ Salah satu kompetensi wajib yang harus dikuasai bidan di ruang bersalin adalah resusitasi neonatus. Pelatihan resusitasi di fasilitas kesehatan telah terbukti mengurangi jumlah kematian neonatus intrapartum sebesar 30\%. ${ }^{3}$ Resusitasi sebagai manajemen asfiksia bayi baru lahir merupakan salah satu topik/materi keterampilan dalam kurikulum mata kuliah asuhan kegawatdaruratan maternal dan neonatal dan menjadi program unggulan di Prodi Kebidanan Poltekkes Palembang.

Dosen sebagai pendidik profesional selain menjalankan tugas utamanya dalam pendidikan dan pengajaran juga memiliki tugas lain sebagaimana tercantum dalam Tri Darma Perguruan Tinggi. Seorang dosen tidak hanya melakukan aktivitasnya di dalam kampus saja untuk dapat melaksanakan tugas profesionalismenya. Sehingga diperlukan suatu strategi pembelajaran yang mampu mengatasi keterbatasan waktu dan ruang bagi dosen untuk tetap dapat menjalankan tugas utamanya selain melakukan kegiatan pengembangan diri di luar kampus. ${ }^{3}$

Revolusi industri 4.0 yang saat ini mengalami puncaknya dengan lahirnya teknologi digital memberikan dampak masif terhadap gaya hidup manusia di seluruh dunia. Revolusi industri generasi keempat mendorong sistem otomatisasi di dalam semua proses aktivitas termasuk pada sektor pendidikan. ${ }^{4}$ Tahun 2012 Menteri Pendidikan dan Kebudayaan telah memberlakukan Permendikbud No. 24 tahun 2012 tentang Penyelenggaraan Pendidikan Jarak Jauh, yang dituangkan oleh Kementerian Riset, Teknologi dan Pendidikan Tinggi dalam buku Panduan Pelaksanaan Pendidikan Jarak Jauh 2016, salah satunya mengarah ke pembelajaran terpadu atau blended learning. 5,6

Strategipembelajaranblendedlearning (pembelajaran campuran) merupakan salah satu solusi yang tepat untuk mengatasi keterbatasan ruang dan waktu yang menjadi kendala bagi dosen dalam proses pembelajaran. Menurut Krause, ${ }^{7}$ blended learning diwujudkan dalam lingkungan belajar mengajar dimana ada integrasi yang efektif dari berbagai mode penyampaian, model pengajaran dan gaya belajar sebagai hasil dari penerapan strategi dan pendekatan sistematis terhadap penggunaan teknologi yang dikombinasikan dengan interaksi tatap muka. Keberhasilan suatu proses pembelajaran dapat dilihat dari pencapaian hasil belajar dan capaian pembelajaran. Fase dalam proses belajar inilah yang dikenal dengan retensi.8 Namun sayangnya faktor retensi kurang mendapat perhatian padahal retensi belajar dapat dijadikan indikator bermutunya hasil belajar atau pembelajaran. 
Berdasarkan penelusuran yang penulis lakukan, belum ada penelitian yang mengukur pengaruh blended learning berbasis google classroom terhadap retensi keterampilan resusitasi pada mahasiswa diploma tiga kebidanan, sehingga penelitian ini merupakan sesuatu yang baru untuk memperkuat teori pengembangan kurikulum kebidanan khususnya pada materi keterampilan klinik yang sesuai dengan kebutuhan institusi pendidikan dengan menggunakan model blended learning berbasis google classroom sehingga mahasiswa mampu mencapai tingkat retensi keterampilan yang diharapkan.

\section{METODE}

Rancangan penelitian yang digunakan dalam penelitian ini adalah eksperimen dengan desain eksperimen semu (Quasi Experiment Design) dengan rancangan Posttest Only Non-Equivalent Group Design. Di dalam desain ini untuk mengukur tingkat retensi keterampilan resusitasi dilakukan melalui 3 tahapan; (1) memberikan post-test pada dua kelompok untuk mengetahui hasil belajar setelah diberikan perlakuan, dimana kelompok eksperimen mendapat pelatihan keterampilan resusitasi neonatus secara online dengan membuat video praktik resusitasi neonatus secara mandiri dan mempostingnya kedalam aplikasi google classroom serta mendapat feedback dari dosen ditambah pelatihan keterampilan tatap muka (blended learning), sedangkan kelompok kontrol mendapatkan dua kali pelatihan keterampilan secara tatap muka saja (konvensional), post-test diberikan setelah mahasiswa mencapai tingkat mahir pada sesi pelatihan, dan post-test diberikan dalam bentuk tes obyektif pilihan ganda dan pernyataan benar salah mengenai tahapan atau prosedur resusitasi neonatus, (2) melakukan retensi memori 1 tentang mahasiswa terhadap keterampilan resusitasi neonatus pada dua kelompok setelah dua minggu post-test, (3) melakukan tes retensi 2 terhadap retensi memori keterampilan resusitasi neonatus pada dua kelompok setelah empat minggu post-test. Pola desain penelitian dapat dilihat pada Tabel 1.

Tabel 1. Desain Penelitian

\begin{tabular}{|c|c|c|c|c|c|c|}
\hline Kelompok & Perlakuan & Post-test & Selang Waktu & Retest 1 & Selang Waktu & Retest 2 \\
\hline $\begin{array}{l}\text { Eksperimen } \\
\text { Kontrol }\end{array}$ & $\begin{array}{l}\mathrm{Xa} \\
\mathrm{Xb}\end{array}$ & $\begin{array}{l}\text { Oa1 } \\
\text { Ob1 }\end{array}$ & 2 Minggu & $\begin{array}{l}\mathrm{Oa} 2 \\
\mathrm{Ob2}\end{array}$ & 4 minggu & $\begin{array}{l}\text { Oa3 } \\
\text { Ob3 }\end{array}$ \\
\hline
\end{tabular}

Keterangan:

$\mathrm{Xa}$ : perlakuan kelompok eksperimen dengan pembelajaran blended learning

$\mathrm{Xb}$ : perlakuan kelompok kontrol dengan pembelajaran konvensional

Oa1 : post-test kelompok eksperimen setelah diberikan perlakuan

$\mathrm{Oa} 2$ : retention test 1 pada kelompok eksperimen setelah 2 minggu dari pelaksanaan post-test

$\mathrm{Oa} 3$ : retention test 2 pada kelompok eksperimen setelah 4 minggu dari pelaksanaan post-test

Ob1 : post-test kelompok kontrol setelah diberikan perlakuan

Ob2 : retention test 1 pada kelompok kontrol setelah 2 minggu post-test

Ob3 : retention test 2 pada kelompok eksperimen setelah 4 minggu post-test

\section{HASIL DAN PEMBAHASAN}

Penelitian tentang pengaruh blended learning terhadap tingkat retensi memori keterampilan resusitasi neonatus telah dilakukan pada mahasiswa Program Studi DIII Kebidanan Poltekkes Palembang semester IV sebanyak 78 mahasiswa yang terbagi menjadi dua kelompok, yaitu kelompok intervensi dan kelompok kontrol yang memenuhi kriteria inklusi. Pada penelitian ini tidak semua subyek penelitian (78 mahasiswa) dapat diikutsertakan dalam tahap analisis hasil penelitian. Sebanyak 6 orang responden dikategorikan dalam kelompok drop out dan 22 orang masuk dalam kriteria eksklusi, sehingga jumlah responden yang memenuhi kriteria adalah 50 orang yang terdiri dari 25 orang responden pada kelas A (kelompok intervensi) dan 25 orang responden pada kelas B (kelompok kontrol).

Implementasi blended learning terhadap tingkat retensi memori keterampilan neonatus dilaksanakan selama 10 minggu (akhir Maret sampai pertengahan 
Mei 2018). Terhadap semua subyek dilakukan pengukuran tes obyektif tentang prosedur praktik resusitasi neonatus kemudian dilakukan retensi tes 1 dan retensi tes 2. Berdasarkan hasil penelitian dapat dilihat karakteristik responden pada Tabel 2.

Tabel 2. Karakteristik Subyek Penelitian

\begin{tabular}{|c|c|c|c|}
\hline \multirow[b]{2}{*}{ Karakteristik } & \multicolumn{2}{|c|}{ Kelompok } & \multirow[b]{2}{*}{ Nilai $p$} \\
\hline & $\begin{array}{l}\text { Intervensi } \\
(\mathrm{n}=25)\end{array}$ & $\begin{array}{l}\text { Kontrol } \\
(n=25)\end{array}$ & \\
\hline $\begin{array}{l}\text { 1. IPK } \\
\text { X (SD) } \\
\text { Rentang } \\
\text { - Sangat } \\
\text { memuaskan } \\
\text { - Cumlaude }\end{array}$ & $\begin{array}{l}3,26(0,15) \\
3,03-3,62 \\
23\end{array}$ & $\begin{array}{l}3,22(0,10) \\
3,03-3,43 \\
25\end{array}$ & $0,305^{*}$ \\
\hline $\begin{array}{l}\text { 2. Post Test } \\
\text { X (SD) } \\
\text { Median } \\
\text { Rentang }\end{array}$ & $\begin{array}{l}65,3(13,7) \\
66,7 \\
41,7-100\end{array}$ & $\begin{array}{l}64,3(14,1) \\
58,3 \\
41,7-91,7\end{array}$ & $0,804 * *$ \\
\hline
\end{tabular}

Keterangan: *) uji-t tidak berpasangan; **) uji Mann-Whitney.

Data skor tes retensi 1 dan tes retensi 2 dikategorikan menjadi tingkat retensi memori keterampilan resusitasi neonatus. Tingkat retensi memori keterampilan neonatus dikonversikan ke dalam nilai 100 , lalu dikategorikan ke dalam skala baik jika skornya $\geq 70 \%$, sedang jika skornya $60-70 \%$, dan kurang jika skornya $<60 \%$. Tingkat retensi memori keterampilan resusitasi neonatus antara kelompok blended learning dan kelompok konvensional dapat dilihat pada Tabel 3.

Tabel 3. Perbedaan Tingkat Retensi Memori Keterampilan Neonatus antara Kelompok Blended Learning dan Kelompok Kovensional

\begin{tabular}{|c|c|c|c|}
\hline \multirow[b]{2}{*}{ Tingkat Retensi } & \multicolumn{2}{|c|}{ Kelompok } & \multirow[b]{2}{*}{$\begin{array}{l}\text { Nilai } \\
p\end{array}$} \\
\hline & $\begin{array}{l}\text { Blended } \\
\text { Learning } \\
(\mathrm{n}=25)\end{array}$ & $\begin{array}{l}\text { Konvensional } \\
\quad(\mathrm{n}=25)\end{array}$ & \\
\hline $\begin{array}{l}\text { 1. Retensi } 1 \\
\text { - Rendah } \\
(<60 \%)\end{array}$ & 2 & 1 & $1,0 *$ \\
\hline $\begin{array}{l}\cdot \text { Sedang } \\
(60-70 \%)\end{array}$ & 1 & 1 & \\
\hline $\begin{array}{l}\cdot \text { - Tinggi } \\
(\geq 70 \%)\end{array}$ & 22 & 23 & \\
\hline
\end{tabular}

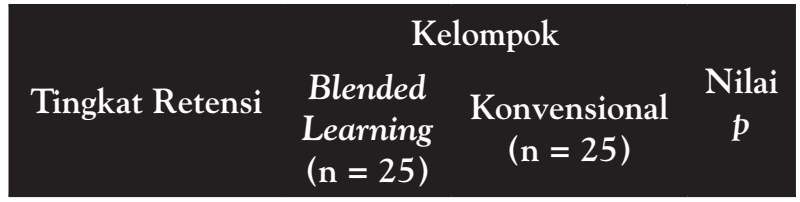

\begin{tabular}{cccc}
2. & Retensi 2 \\
$\cdot$ Rendah & 1 & 1 & $1,0^{*}$ \\
$(<60 \%)$ & & & \\
$\cdot$ Sedang & 1 & 2 & \\
$(60-70 \%)$ & & & \\
$\cdot \begin{array}{c}\text { Tinggi } \\
(\geq 70 \%)\end{array}$ & 23 & 22 & \\
\hline
\end{tabular}

Keterangan: *) Uji Kolmogorov-Smirnov

Hubungan persepsi mahasiswa tentang implementasi blended learning terhadap tingkat retensi memori 1 dan 2 pada keterampilan resusitasi neonatus pada kelompok intervensi dapat dilihat pada Tabel 4 dan Tabel 5. Dari hasil analisis diketahui bahwa tidak terdapat hubungan antara persepsi mahasiswa tentang implementasi blended learning dengan tingkat retensi memori 1 dan retensi 2 keterampilan resusitasi neonatus pada kelompok intervensi.

Tabel 4. Hubungan Persepsi Mahasiswa tentang Blended Learning Terhadap Tingkat Retensi

Memori 1 Keterampilan Resusitasi Neonatus pada Kelompok Intervensi

\begin{tabular}{lccc} 
Persepsi & \multicolumn{3}{c}{ Retensi 1 } \\
& Rendah & Sedang & Tinggi \\
Negatif & $1(7,1 \%)$ & 0 & $13(92,9 \%)$ \\
Positif & $1(9,1 \%)$ & $1(9,1 \%)$ & $9(81,8 \%)$ \\
\hline
\end{tabular}

Keterangan: Nilai $p=0,50$; Korelasi $p h i=0,236$

Tabel 5. Hubungan Persepsi Mahasiswa tentang Blended Learning dengan Tingkat Retensi

Memori 2 Keterampilan Resusitasi Neonatus pada Kelompok Intervensi

\begin{tabular}{lccc} 
Persepsi & \multicolumn{3}{c}{ Retensi 2 } \\
& Rendah & Sedang & Tinggi \\
Negatif & 0 & 0 & $14(100 \%)$ \\
Positif & $1(9,1 \%)$ & $1(9,1 \%)$ & $9(81,8 \%)$ \\
\hline
\end{tabular}

Keterangan: Nilai $\mathrm{p}=0,251$; Korelasi phi $=0,333$ 


\section{Tingkat Retensi Memori Keterampilan} Resusitasi Neonatus pada Kelompok Blended Learning dan Kelompok Konvensional

Hasil penelitian ini menunjukkan bahwa strategi pelatihan keterampilan blended learning yang memadukan pelatihan keterampilan online berbasis google classroom dan satu kali latihan keterampilan tatap muka telah teruji menghasilkan tingkat retensi memori yang sama dengan dua kali latihan keterampilan konvensional, sehingga blended learning dapat dijadikan strategi dalam pembelajaran praktik kebidanan.

Ada beberapa keunggulan pelatihan keterampilan blended learning dibandingkan pelatihan keterampilan konvensional. Keunggulan pertama dilihat dari aspek proses belajar; melalui pelatihan keterampilan blended learning berbasis google classroom dapat mengaktifkan proses berfikir metakognitif dan proses self- learning sehingga sesuai dengan teori Piaget $^{9}$ bahwa perkembangan kognitif dipengaruhi oleh pengalaman. Belajar berbasis pengalaman ini telah digambarkan dalam siklus Kolb. ${ }^{10}$ Salah satu siklus Kolb adalah pengalaman konkret dimana pembelajar secara aktif berpartisipasi dalam pengalaman, seperti simulasi pada sesi laboratorium atau kerja lapangan.

Tugas yang diberikan pada pelatihan keterampilan blended learning mendorong mahasiswa untuk berlatih secara mandiri secara berulangulang (rehearsal) melalui simulasi terstruktur sehingga dapat mengembangkan pengetahuan, keterampilan, dan sikap profesional kesehatan, termasuk melindungi pasien dari risiko yang tidak perlu. Latihan ini dilakukan mahasiswa dengan menggunakan phantom yang dipraktikan di ruang laboratorium secara berulang-ulang sampai akhirnya mahasiswa mahir dan bisa mendokumentasikan pengalaman praktik mandirinya menjadi video yang akan diunggah ke dalam aplikasi google classroom secara online. Sehingga frekuensi latihan mahasiswa pada kelompok blended learning akan lebih sering dibandingkan frekuensi latihan pada kelompok pelatihan konvensional. Fase inilah yang menjadi pengalaman konkret sesuai pada fase pertama Kolb. ${ }^{10}$ Proses belajar melalui experiential learning yaitu pengetahuan diciptakan melalui tranformasi pengalaman konkret. Pengalaman yang diperoleh akan membentuk pengetahuan baru mahasiswa dan akan menghasilkan pengetahuan berdasarkan pengalaman mereka. ${ }^{11}$ Pada sesi pertemuan tatap muka pada pelatihan keterampilan blended learning, dosen mendemonstrasi praktik resusitasi neonatus secara langsung, sehingga mahasiswa secara sadar akan merefleksikan kembali pengalaman praktik resusitasi yang sudah mereka kerjakan sebelumnya. Fase ini disebut fase pengamatan reflektif. ${ }^{12,13}$

Belajar melalui pengalaman yang dilakukan mahasiswa pada pertemuan online merupakan pembelajaran efektif karena proses belajar berpusat pada mahasiswa (SCL) dimana mahasiswa aktif berlatih secara mandiri membangun pengetahuannya secara terstruktur dan fokus pada aplikasi praktik resusitasi neonatus. Selain itu, mahasiswa menjadi lebih fokus belajar dan disiplin untuk menyelesaikan tugas yang diberikan dosen bila dibandingkan dengan pelatihan keterampilan konvensional, karena pada pelatihan keterampilan blended learning video hasil praktik mandiri terdokumentasi di dalam aplikasi google classroom. Hal inilah yang membuat belajar berbasis pengalaman menjadi efektif karena proses belajar pelatihan keterampilan blended learning ini menekankan pada strategi belajar sehingga dapat melatih proses berfikir metakognitif.

Proses pelatihan keterampilan blended learning ini merupakan proses pembelajaran yang konstruktif. Berdasarkan pespektif teori, konstruktivisme adalah memotivasi dan mengarahkan mahasiswa mempelajari materi melalui proses inquiry sesuai dengan karakteristik masing-masing mahasiswa, sehingga mahasiswa akan aktif untuk belajar dan disiplin mengerjakan tugas sesuai dengan paradigma "student centered learning" (SCL). Penerapan SCL dalam proses belajar menjadikan proses pembelajaran konstruktivisme karena berfokus pada mahasiswa dan mahasiswa terlibat langsung dalam proses pembelajaran itu sendiri, bagaimana mereka berfikir dan memahami sumber belajar agar pengetahuan yang sudah ada dapat berasimilasi dan diakomodasi menjadi pengetahuan yang baru. ${ }^{11-15}$ Teori belajar kontrutivisme bependapat bahwa pada proses pembelajaran konstruktif dosen 
hanya berfungsi sebagai fasilitator yang melatih, memberikan feedback atau umpan balik baik secara online maupun offline dan membantu mahasiswa mengembangkan pemahaman mereka sendiri. Feedback menjadi penting pada proses blended learning karena dapat membantu siswa untuk menilai penampilan (kemampuan) yang tidak bisa dilihat dan dirasakannya sendiri, selain itu feedback yang diberikan dosen dapat menjadi motivasi ataupun penguatan bagi mahasiswa untuk terus berlatih memperbaiki langkah-langkah yang belum sempurna. ${ }^{9,16}$

Proses pemberian feedback pada pelatihan keterampilan blended learning terjadi secara online setelah mahasiswa mengunggah tugas video praktik mandirinya ke dalam google classroom, dan secara tatap muka pada saat mahasiswa mendemonstrasikan kembali dengan bimbingan dosen.

Keunggulan kedua, pada pelatihan keterampilan blended learning berbasis googgle classroom aktivitas belajar terdokumentasi dalam aplikasi. Mulai dari penugasan sampai dengan feedback dari dosen dan proses diskusi antara dosen dan mahasiswa dapat dilihat dalam aplikasi, sehingga bisa diakses sewaktu-waktu sebagai bahan belajar mahasiswa.

Keunggulan ketiga, lebih efektif dan efisien dari aspek waktu dan tenaga. Pelatihan keterampilan blended learning lebih efektif dan efisien bila dibandingkan pelatihan keterampilan konvensional, karena pada proses pelatihan keterampilan blended learning mahasiswa mengatur sendiri waktu belajar mereka sesuai dengan cara dan karakteristik masing-masing, sedangkan bagi dosen pelatihan keterampilan blended learning dapat menyiasati keterbatasan waktu dan ruang pada saat dosen harus tetap melaksanakan tugas Tridarma lainnya.

Satu hal yang dapat disimpulkan dari penelitian ini bahwa pelatihan keterampilan blended learning berbasis google calssroom sama efektifnya dengan dua kali pelatihan keterampilan konvensional, karena tingkat retensi memori keterampilan resusitasi neonatus yang dihasilkan sama atau sebanding.

Hasil penelitian ini hampir serupa dengan hasil penelitian Qian Liu $\mathrm{dkk}^{17}$ yang menyimpulkan bahwa blended learning memiliki efek positif yang konsisten dibandingkan dengan tanpa intervensi atau nonblended learning (e-learning murni atau konvensional tatap muka), dan lebih efektif daripada atau setidaknya sama efektifnya dengan instruksi nonblended untuk tingkat pengetahuan pada profesi kesehatan.

Pada penelitian ini terdapat beberapa kondisi atau faktor yang dapat memengaruhi hasil penelitian. Faktor pertama adalah penerapan blended learning pada materi praktik resusitasi neonatus berbasis google classroom merupakan suatu pengalaman belajar yang baru bagi mahasiswa. Pembelajaran praktik kebidanan sebelumnya lebih banyak didominasi dengan pertemuan tatap muka. Sehingga, sebelum penerapan blended learning mahasiswa telah diberikan sosialisasi dan simulasi mengenai pemanfaatan google classroom.

Faktor kedua, kurikulum pendidikan menggunakan sistem blok sehingga menyebabkan waktu penelitian antara kelompok intervensi dengan kelompok kontrol tidak dapat dilakukan dalam waktu bersamaan.

Faktor ketiga, sebagian mahasiswa tinggal di dalam satu asrama, sehingga menyebabkan terjadinya pertukaran informasi yang begitu cepat antara mahasiswa dari kelompok intervensi dengan mahasiswa kelompok kontrol. Hal ini menyebabkan munculnya subyektifitas pada kelompok kontrol untuk mendapatkan nilai yang lebih tinggi saat post-test dan pretest.

Faktor keempat, kurangnya respon mahasiswa terhadap feedback yang diberikan dosen pada video yang diunggah. Mahasiswa hanya membaca feedback yang diberikan dosen tanpa merespon kembali, sehingga forum diskusi tidak berjalan seperti yang diharapkan. Beberapa alasan yang disampaikan mahasiswa bahwa mereka sulit memahami feedback yang diberikan dosen dan mahasiswa lebih menyukai demonstrasi pada pertemuan tatap muka karena mereka bisa berinteraksi langsung dengan dosen dan pertemuan tatap muka dirasakan mahasiswa lebih interaktif dibandingkan pertemuan online. Hal ini sebagaimana diungkapkan dalam teori Roger ${ }^{19}$ yang menyatakan bahwa salah satu ciri belajar adalah belajar yang bermakna yaitujika dalam 
proses pembelajaran melibatkan aspek pikiran dan perasaan peserta didik.

Faktor kelima, dosen belum terbiasa memberikan feedback secara online, dan juga belum adanya panduan atau format khusus yang dibuat untuk memberikan feedback secara online pada video yang diunggah. Sehingga feedback hanya secara umum dan tertuju pada poin-poin penting saja.

Hasil uji statistik deskriptif pada kuesioner persepsi menunjukan bahwa sebanyak 44\% mahasiswa memiliki persepsi positif sedangkan 56\% memiliki persepsi negatif terhadap implementasi blended learning. Hal ini menyimpulkan bahwa menurut persepsi mahasiswa materi keterampilan resusitasi dirasakan kurang cocok dilakukan dengan cara blended learning. Selama ini proses latihan keterampilan yang dilakukan di Prodi DIII Kebidanan Poltekkes Palembang lebih didominasi oleh demonstrasi tatap muka saja, karena itu blended learning berbasis google classroom pada mata kuliah praktik merupakan suatu proses pembelajaran yang baru pertama kali diterapkan. Mahasiswa memerlukan waktu untuk membiasakan diri melaksanakan latihan demonstrasi secara online. Mahasiswa juga memerlukan waktu untuk berlatih membuat dan mengunggah video demonstrasi ke dalam google classroom. Masa adaptasi tersebut tetap diperlukan meskipun sebelumnya mahasiswa sudah mendapatkan sosialisasi mengenai pemanfaatan google classroom.

Sebagian besar mahasiswa memiliki persepsi negatif terhadap implementasi blended learning, namun bila dilihat berdasarkan pernyataan kuesioner no. 8 yang menyatakan bahwa pertemuan tatap muka/ offline pada blended learning terasa lebih bermakna, 96\% mahasiswa menjawab setuju. Seesuai teori akuisisi keterampilan bahwa pada proses belajar online, mahasiswa mencari sumber belajar sendiri (fase deklaratif) sedangkan pada proses belajar offline mahasiswa melakukan demonstrasi dengan menjelaskan setiap tahapan yang dikerjakan kemudian instruktur memberikan feedback, sehingga mahasiswa merasakan proses yang lebih nyata dan lebih berkesan karena secara langsung melibatkan pikiran dan perasan dibandingkan pada pertemuan online saja. ${ }^{15}$
Hasil penelitian menunjukkan bahwa mahasiswa memiliki persepsi negatif terhadap blended learning, namun hal ini bertentangan dengan peryataan kuesioner no. 9 bahwa sebesar 100\% mahasiswa mendukung diterapkan blended learning, dari pernyataan ini dapat disimpulkan bahwa sebenarnya mahasiswa merasakan blended learning memberikan pengaruh positif terhadap latihan keterampilan resusitasi neonatus, hanya saja mahasiswa membutuhkan waktu untuk menguasai strategi belajar keterampilan secara blended.

Faktor lain yang juga memengaruhi retensi adalah perbedaan karakteristik mahasiswa. Perbedaan karakteristik mahasiswa menyebabkan perbedaan sikap, minat, nilai, dan konsep diri mahasiswa terhadap proses pembelajaran blended, sehingga memengaruhi cara mahasiswa dalam menyikapi dan melaksanakan proses pembelajaran. Selain itu, faktor kondisi fisik dan psikis pada saat proses belajar dapat memengaruhi retensi mahasiswa. Pada penelitian ini, faktor waktu yang relatif singkat ( $2 \times 24 \mathrm{jam})$ untuk mahasiswa menyelesaikan tugas mandiri berupa pembuatan video resusitasi secara online ke dalam google classroom, secara tidak langsung membuat mahasiswa merasa terbebani secara psikis. Semb dan Elis ${ }^{16}$ menyatakan bahwa faktor-faktor yang dapat memengaruhi masuknya pengetahuan ke long term memory adalah tingkat dari materi yang dipelajari, tugas yang harus dipelajari, strategi/metode pembelajaran, dan perbedaan individual.

Hasil penelitian menunjukkan sebagian besar mahasiswa memiliki persepsi negatif terhadap implementasi blended learning, namun berdasarkan hasil jawaban kuesioner persepsi pada pernyataan no. 13 yang menyatakan "blended learning membuat saya belajar aktif dan mandiri" 96\% mahasiswa menjawab setuju. Hal ini menunjukkan bahwa mahasiswa mengakui dengan blended learning mereka menjadi lebih aktif belajar sendiri. Hasil penelitian ini sejalan dengan penelitian $\operatorname{Anan}^{20}$ yang menyimpulkan bahwa model pembelajaran blended learning efektif meningkatkan kemandirian belajar dimana berpengaruh 48,2\% terhadap peningkatan kemandirian peserta didik program paket C. Begitupun untuk pernyataan kuesioner no. 14 yang menyatakan "perkuliahan dengan 
blended learning membuat saya disiplin mengerjakan tugas" $100 \%$ mahasiswa menjawab setuju. Hal ini juga membuktikan bahwa blended learing efektif memberikan pengaruh positif bagi mahasiswa, karena dengan menerapkan strategi blended learning pada praktik resusitasi neonatus membuat mahasiswa disiplin dalam mengerjakan tugas mandirinya dibandingkan dengan pelatihan keterampilan konvensional.

\section{KESIMPULAN}

Penelitian ini menunjukkan bahwa blended learning merupakan strategi pembelajaran praktikum yang efektif dibandingkan pembelajaran konvensional. Tingkat retensi memori keterampilan resusitasi neonatus antara pelatihan keterampilan blended learning sama dengan pelatihan keterampilan konvensional. Selain itu, persepsi mahasiswa tentang implementasi blended learning tidak berpengaruh terhadap tingkat retensi memori keterampilan.

\section{SARAN}

Perlu dilakukan penelitian lebih lanjut dengan rancangan penelitian yang berbeda dalam satu periode waktu yang sama antara pelatihan keterampilan blended learning dan pelatihan keterampilan konvensional sehingga mengurangi dapat bias dan hasil yang diharapkan dapat tercapai. Perlu dilakukan penelitian lanjut tentang persepsi dosen terhadap implementasi blended learning pada pembelajaran praktik sebagai bahan evaluasi.

\section{DAFTAR PUSTAKA}

1. Survey Development Goals Cbot; 2015.

2. Kementerian Kesehatan RI. Kurikulum Inti Pendidikan Diploma III Kebidanan. Jakarta: Kemenkes RI; 2011.

3. Kementerian Kesehatan RI. Peraturan Menteri Kesehtan Republik Indonesia No.49 Tahun 2015. Jakarta; 2015.

4. Rosyadi Slamet. Revolusi Industri 4.0: Peluang dan Tantangan Bagi Alumn Universitas Terbuka. Fakultas Ilmu Sosial dan Politik Universitas Jenderal Soedirman; 2018.

5. Peraturan Menteri Pendidikan dan Kebudayaan RI No.24 Tahun 2012 tentang Penyelenggaraan Pendidikan Jarak Jauh. 2012.
6. Kementerian Riset Teknologi dan Pendidikan Tinggi. Kebijakan Pendidikan Jarak jauh dan E-Learning di Indonesia; 2016.

7. Janner SA, Janulis P. Purba E. Djuanda A. Implementasi Model Pembelajaran Berbasis Blended Learning Untuk Meningkatkan Hasil Belajar Siswa. Prosiding Seminar Nasional Inovasi dan Teknologi Informasi. 2016 11-12 November 2016:1845-8.

8. Robert L, Solso OHM, Maclin MK. Psikologi Kognitif. Edisi Kedelapan. Penerbit Erlangga; 2007.

9. Rusli L. Belajar Keterampilan Motorik, Pengantar Teori dan Metode. Jakarta: Depdikbud Dirjen Dikti Proyek Pengembangan Lembaga Pendidikan Tenaga Kependidikan; 1988.

10. Lateef F. Simulation-Based Learning: Just Like The Real Thing. Journal Of Emergencies Trauma And Shock. 2010 Oct-Dec;3 (4):348-52.

11. Suhendi A, Purwarno. Constructivist Learning Theory: The Contribution to Foreign Language Learning ad Teaching. Kne Social Science \& Jumanities. 2018;87-95.

12. Kolb D, Kolb AY. Experiential Learning: Experience as Source of Learning and Development. PrenticeHall, Inc. Englewood Cliffs, N.JI; 1984

13. Bartle E. Experiential Learning: an overview. The University Of Queensland. Austraia. 2015

14. Bourke John, Debra Bath. Getting Started With Blended Learning: Griffith University. 2010.

15. Julie A, Poore M, Deborah L, Cullen ED, Gina L, Schaar DNP. Simulated-Based Interprofesional Education Guided by Kolb's Experietial Learning Theory. Clinical Simulation in Nursing. 2014;10:241-7.

16. Suherman A. Revitalisasi Keterlantaran Pengajaran Dalam Pendidikan Jasmani. Bandung: IKIP Bandung Press; 1998.

17. Liu Q, Peng W, Zhang F, Hu R, Li Y, Yan W. The Effectiveness of Blended Learning in Health Professions: Systematic Review and Meta-Analysis. Journal of Medical Internet Research. 2016;01(04).

18. Bourke DBaJ. Getting Started With Blended Learning: Griffith University; 2010.

19. Makmun K. Psikologi Belajar. 1 ed. Sleman, Yogyakarta: Aswaja Pressindo; 2017.

20. Sutisna A. Pengembangan Model Pembelajaran Blended Learning pada Pendidikan Kesetaraan Program Paket Cdalam Meningkatkan Kemandirian Belajar. Jurnal Teknologi Pendidikan. Desember 2016; Volume 18, No.3. 